\title{
Spatial Connectivity of Indonesian Shop Houses
}

\author{
Lya Dewi Anggraini
}

Doctoral student, Department of Built Environment, Interdisciplinary Graduate School of Science and Engineering Tokyo Institute of Technology, Japan

anggraini.l.aa@m.titech.ac.jp.

\begin{abstract}
Given the very high variety of self-built shop houses in Indonesia, this paper unfolds the pattern of the shop house layout through its spatial connectivity. The method of Hillier and Hanson (1984) is modified and used to discover the type of connectivity and its effect to the functional spaces. By analyzing samples from Chinese \& Javanese settlement in Yogyakarta, the result shows that the spatial connectivity of the Chinese shop houses has the inclination of direct connectivity than is the Javanese. This may assume that in Chinese shop houses the access to the rooms is more strictly controlled and circulation is more regulated than in Javanese shop houses. Further results also show the distinct characteristic differences that are inward/outward orientation, multi-unit/single-unit, linear/cluster organization, and closeness/openness.
\end{abstract}

Keywords: Shop house; Chinese; Javanese; Spatial Connectivity

eISSN 2514-751X @ 2018. The Authors. Published for AMER ABRA cE-Bs by e-International Publishing House, Ltd., UK. This is an open access article under the CC BY-NC-ND license (http://creativecommons.org/licenses/bync-nd/4.0/). Peer-review under responsibility of AMER (Association of Malaysian Environment-Behaviour Researchers), ABRA (Association of Behavioural Researchers on Asians) and cE-Bs (Centre for EnvironmentBehaviour Studies), Faculty of Architecture, Planning \& Surveying, Universiti Teknologi MARA, Malaysia.

DOI: https://doi.org/10.21834/aje-bs.v3i7.268 


\subsection{Introduction}

"...as cultural rules change, so do the activities appropriate to various settings and also the cues. This is important both for understanding cultural differences and for situations of cultural change (especially rapid culture change) common today, and therefore, for design-for example, in housing." (Rapoport, 2005)

Self-provided housing has continued to increase and covers roughly $90 \%$ of the housing supply in Indonesia. Private sectors as well as individuals have a long journey in accommodating houses for ordinary citizens. As a big country with a rich number of ethnic varieties, little did studies link this rich social cultural with the type and variety of the new emergence housing especially in urban areas, partly because they require extra effort and permission to enter private houses. However, to think of the considerably high number and concern for the seemingly uncontrolled and apparently eclectic design, this has called professionals to put their hands to the in- depth research on ordinary housing.

Shop houses are an adaptive respond to the immediate housing need and preferable for those who'd plan to support their household economy. This type of house is currently popular among urban dwellers. This study has chosen several shop houses where family lives and works in their house by opening the shop. There are at least two kinds, the ones that were built at fist as an ordinary house and others that were built from the beginning as a shop house. Particularly shop house is not the original type of house in Yogyakarta, but Chinese ethnic citizens had introduced this type to the locals. With no particular and strict building codes many urban dwellers have then loosely adopted this multi-function house and take advantage ofit.

This study concerns with the changes made from an ordinary house into shop house and attempts at comparing it with the ubiquitous Chinese shop house. Unlike an ordinary house whose spaces become the focus of analysis as done by Shoul (1993), in the shop house is the circulation important. Thus, this paper aims at analyzing the spatial connection of the house layout. By comparing the spatial connectivity in shop houses built by Chinese and Javanese, any distinct characteristic would be revealed. Further, it will reveal how this multipurpose houses will have affected the interior spaces as a whole through the functions which encode the behavioral aspect by composing and using interior spaces. This study finds that there are distinct characteristic differences between Chinese and Javanese in the use of a single building for both living and working.

\section{Development of Shop House and Cultural Influence}

While Chinese shop house has become popular in Java by the Chinese immigrants who flooded into Indonesia during the colonialism period in the 16th century, the Javanese traditional architecture does not have a type of shop house(Pratiwo, 2010:243). In otherwords, the Chinese first introduced the shop house building from their homeland. This has become a worldwide archetype. Apparently the Javanese have developed their own type of shop house roughly in the last three decades as a response to the local condition. This was not due to Chinese influence alone. It can be traced back from many earlier centuries in different periods at different places that all together have shaped the physical structure and development of architecture and housing in Java which was central to agriculture. 
Most of the Chinese immigrants in Yogyakarta come from the Southern part of Mainland China where they made their living originally in farming. It is said that the earliest model of shop house was a transformation of a farming house where the open space in the middle area was transformed into an air well, which maintained the orientation of the surrounding rooms inwardly to the air well/service area. The other common characteristic of shop house was the whole front area on the first floor was utilized as a shop and the dwelling space was at the back, second floor and any additional areas. These houses were built side by side with a shared construction as row houses in a narrow but a long piece of land for each unit.

On the other hand, the native Javanese also developed a type of shop house. The common characteristics were a single detached house with a separate structure from the main house for the shop or included in the house plan but slightly ahead of the rest of the rooms. Even though some of the houses were built close to each other, but they maintained a separate structure to allow some space between the houses to let the light and fresh air flowing into the rooms, in other words, the Javanese houses are characterized in their outward orientation. Looking at these characteristics of the houses built by Javanese, one may see it as most likely as a transformation from a traditional farming house, too.

In regards to the current situation, where many Javanese have built their houses with either altered function or a designated function as shop, there must have been a lot of changes in the spatial connectivity. In order to clarify and emphasize the result through the cultural differences, this paper is comparing Chinese and Javanese shop house layout.

\section{Characteristics of Chinese and Javanese Shop House in Yogyakarta}

The first observation area was Ketandan in the center of Yogyakarta citynear Beringharjo Market, the oldest and traditional market, where the Chinese built shop houses. The second observation area was Seturan in the new urban center northern part of the city where Javanese built shop houses. Formerly this ethnic segregation was a consequence of political regulation during the colonialism period. Later, during the reign of new order era in 1965 until 1998 the segregation was more due to cultural repression, rather than physical, by prohibiting Chinese language and other cultural activities engaged in public. This caused the assimilation of Chinese to mainstream Javanese and resulted in a void of Chinese culture in many ways, spoken language, physical expression, and activities. However, inwardly there are differences in the shop houses.

\section{Characteristics of Chinese Shop House}

Chinese shop house in Java, particularly in Yogyakarta had some uniqueness through its historical background. There are at least two types, row houses with arcades and without arcades. In Ketandan are those without arcades but a shared roof structure and were constructed as double or triple houses withoutany space between the houses. In the course of time, there have been rapid changes in the interior, yet slower change in the exterior (Anggraini, 2007) (Pratiwo, 2010: 236). Particularly at the northern part of Beringharjo Market which once was known to be material and construction supplier is now revived again with a greater variety of small scale retail goods and services.

Families living in the houses were generally from the first generation that moved into the 
region from different parts of Southern China and built and relied on their own resources. Later generations left these houses for other places with a better environment and more business prospects.
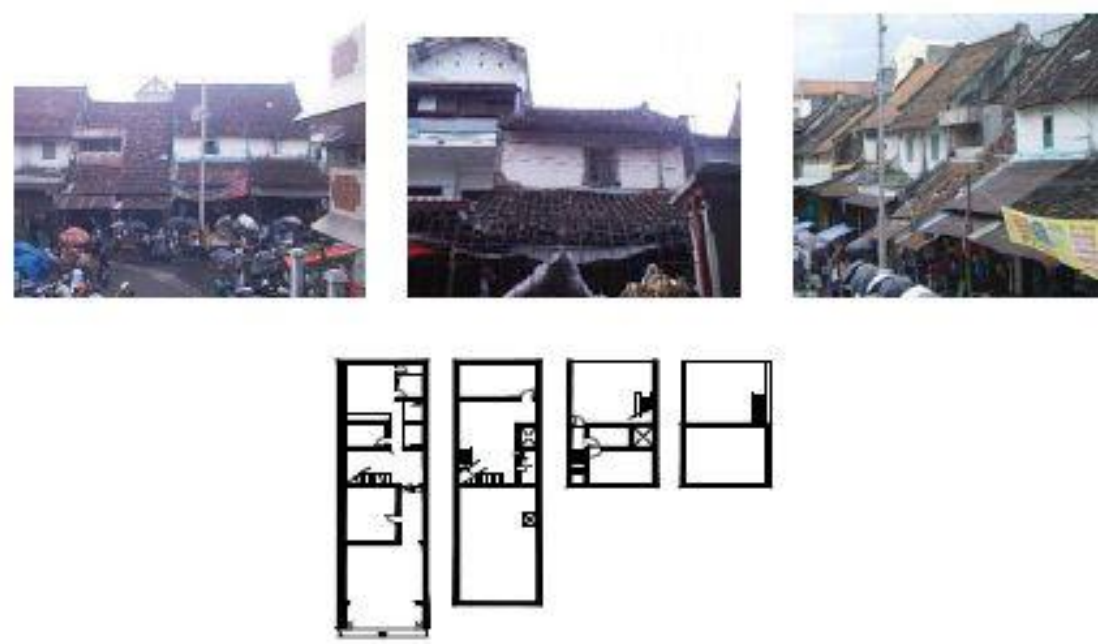

Figure 1: Typical Chinese Shop House
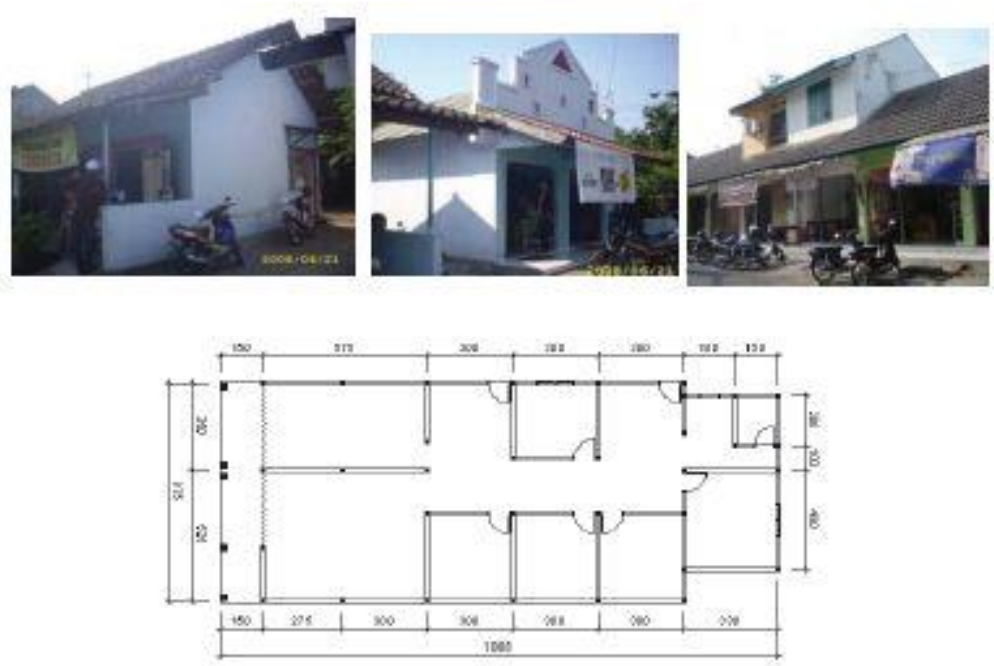

Figure 2: Typical Javanese Shop House

\section{Characteristics of Javanese Shop House}

Shop houses that were built by Javanese in the new urban areas were of great variety from 
very simple to more complex structures. Some houses were an eclectic style freely copied from any design that suited the demand or image of the builder's wishes without any deeper meaning. Generally, they were built as detached houses, not in a row, some with spaces between houses, particularly in the new areas that were less crowded and were built at various time periods.

Families living in the houses were mostly new families moving into the region as newly-weds or immigrants from other areas who were interested in establishing business in this city.

Some of the houses were built and rented to other families

\subsection{Methodology}

Twelve shop houses were chosen in both locations considering the accessible data, limited time and to focus on the qualitative instead of quantitative analysis. A selective sampling method was used with certain criteria as follow; (1) built either by Chinese or Javanese, (2) built on their own initiative without any involvement from professional builders, and (3) irrespective of the age of building or the building shape, and it was accessible for surveying, interviewing, photographing, sketching (to obtain the house plan). All the house plans were redrawn emphasizing the door position for each floor. Each house layout and usagewas then transformed into a diagram of circles representing each functional room and lines representing the door that were drawn from any outside point (threshold) to inside rooms. There are two kinds of lines; a continuous line indicates direct accessibility and a dashed line indicates close/indirect connectivity. This diagram also showed the circulation flow through each functional room and its level of depth.

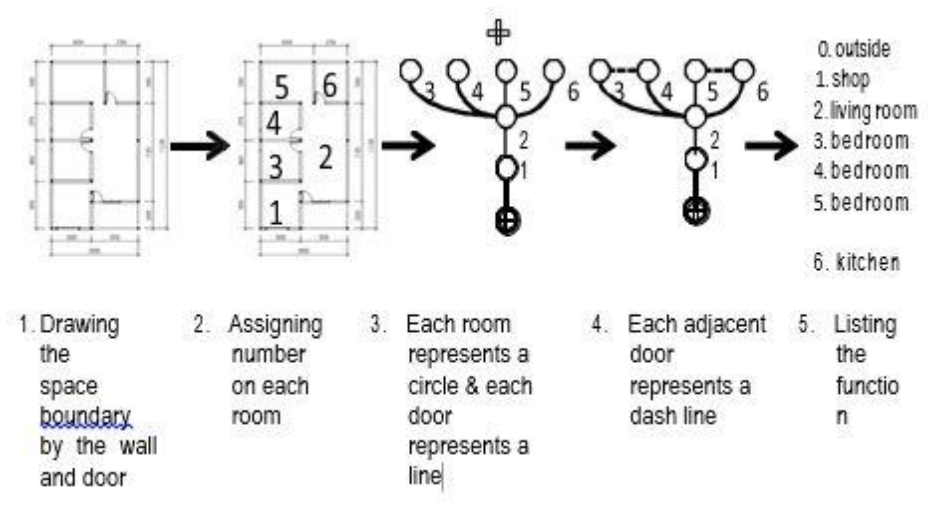

Figure 3: Method of Analysis

The first step, assigning number on the house plan, is important for counting the number of room. Defining the space boundary in the next step is to identify every area in the house plane and include its function. The third step is the most difficult part which will determine all the connections among the defined spaces which enables it to redefine the 
space boundary (back to step 2) before establishing a fixed diagram. The fourth step is assigning the indirect connectivity indicated as dash line on the diagram to determine the degree of connectivity among the spaces. The last step is to list the functional rooms based on the defined space in step 2 according to the activity observed as the actual use.

\subsection{Results and Discussions}

Results of the analysis (see diagram 1 ) showed that the number of room with single connectivity is higher in Chinese (32\%) than in Javanese (26\%), and the number of room with direct connectivity is far higher in Chinese (77\%) than in Javanese (58\%). Additionally, the number of room with indirect connectivity is much higher in Javanese (42\%) than in Chinese (23\%). This alone means that the connection of each room has the tendency to be linear for Chinese and clustered for Javanese. Single and direct connectivity means that one room has one sole access to an adjacent room, whereas indirect connectivity is that one can access a room from any surrounding room within behavioral distance without much barrier/boundary problem.

Although the number of rooms with two, three, and four connectivity is higher in Chinese $(22 \%, 15 \%, 8 \%$ respectively) than in Javanese (13\%, $8 \%, 3 \%$ respectively), rooms with five connectivity is found higher in Javanese (5\%) than in Chinese (1\%). More connectivity means more increase in accessibility. This means that Chinese shop house is more likely to be inwardly oriented, but this is not something apart from function.

In all Chinese shop houses, there were room with three connections that served various functions as such extended shop, corridor, storage, living room, kitchen, and well/washing area, and 4 out of 6 Javanese shop houses hadthree connectionsthatserved various activities suchas corridor, kitchen/ dining room, garage/shop, guestroom, and stairs. However, we found that 5 out of 6 Chinese shop houses had a room with four connections that served as a corridor, but only 2 out of 6 Javanese shop house had room with four connections that served as corridor.

In the Chinese shop house we found one room with five connections that served as a corridor whereas in the Javanese, a room with five connections served as a living room and a dining room. In Javanese we found one room with six connections that served as living room which connected to all other rooms and to the outside. We also found one room with nine connections that served as corridor. Thus, the Javanese rooms showed characteristically greater openness compared to the Chinese.

Furthermore, rooms with higher connectivity in Javanese shop house served as living/dining room which had social meaning, whereas the corridor had no particular function other than circulation/transition space. This meant that even though Chinese shop house seemed to have more rooms with high connectivity and thus inward orientation, it was more likely to be transitional rather than functional room. Therefore, Javanese shop house had outward orientation but also higher functional room inside the houses.

To sum up, having single and direct connectivity considered Chinese shop house as a composition of multiple unit rather than a compound or one single unit. This is emphasized by the corridor as transitional room with high connectivity. On the other hand, Javanese shop 
house was more likely to be compound or single unit which was less repetitive room unit. This may assume that in Chinese shop houses the access to the rooms is more strictly controlled and circulation is more regulated than in Javanese shop houses.

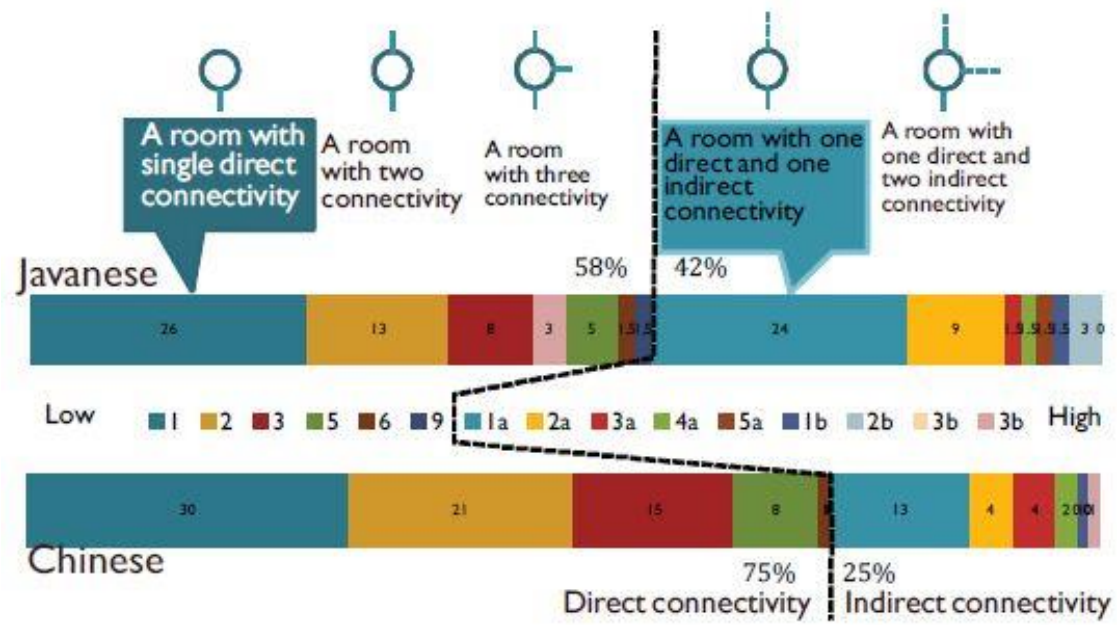

Diagram 1: Distribution and Types of Connectivity

\subsection{Conclusion}

Regardless of the building shape and the house layout or floor area, there were some similarities between the Chinese and Javanese shop houses in terms of the function of the rooms. However, the Javanese shop houses have the overall distinct characteristics of being more open, having a higher degree of connectivity, and tending to be clustered whereas Chinese shop houses tended to be linear and closed in its spatial connectivity. The Javanese shop houses have an outward orientation indicated by the higher number of rooms with access to the outside whereas the Chinese shop house tended to be inwardly orientated.

The architecture of Chinese shop houses in the observed area that were builtduring the colonialism period by the Dutch resemble such in their origin, later they underwent some transformation because of the influences or forces received from locals (Javanese) and others such as the colonial government (Aryanti Dewi, etal., 2005: 18). This paper concluded thateven though there had been some fundamental changes on the space connectivity in order to adjust with the block division system developed by the colonial authorities (Ellisa, 1999: 320), inwardly there has been continuity (Pratiwo 2010: 236) to some extent. This is what made it different from the local architecture (Javanese). 


\section{References}

Anggraini, Lya Dewi. (2007) Tipe Bangunan Rumah Toko Cina di Ketandan Yogyakarta: Berdasarkan Bentukfungsi (Indonesian). Unpublished Master thesis, Gadjah Mada University, Yogyakarta, Indonesia.

Aryanti Dewi and Antariksa, San Soesanto. (2005, July) Pengaruh Kegiatan Berdagang TerhadapPolaRuangDalamBangunan Rumah-TokodiKawasan Pecinan Kota Malang (Indonesian). Dimensi Teknik Arsitektur, 33(1), 1726.

Ellisa, Evawani. (1999, August 3-4 $4^{\text {th }}$ ) Tracing the Adaptation Process of Shop Houses: from Traditional Vernacular into Contemporary Vernacular Settlement. Proceedings of International Seminar on Vernacular Settlement. Jakarta, Indonesia: The Faculty of Engineering University of Indonesia, 315-331.

Habraken, N.J. (1998) The Structure of the Ordinary: Form and Control in the Built Environment. USA: Graphic Composition, Inc.

Lara, Fernando and Kim, Youngchul. (2010, Summer) Built Global, Lived Local: A Study of How Two Diametrically Opposed Cultures Reacted to Similar Modern Housing Solutions. Journal of Architectural and Planning Research. 27(2), 91-105.

Pratiwo. (2010) Arsitektur Tradisional Tionghoa dan Perkembangan Kota (Indonesian). Yogyakarta, Indonesia: Penerbit Ombak.

Rapoport, Amos. (1982) The Meaning of the Built Environment: A Nonverbal Communication Approach.Tucson, UnitedStates ofAmerica:TheUniversity of Arizona Press.

Rapoport, Amos. (2005) Culture, Architecture, and Design. Chicago, Illinois, USA: Locke Science Publishing Company, Inc.

Shoul, Michael. (1993, January) The Spatial Arrangements of Ordinary English Houses. In Environment and Behavior, 25(1), 22-69.

Steinhardt, Nancy Shatzman, et.al. (1984) Chinese Traditional Architecture. New York City: China Institute in America, Inc.

Zahnd, Markus. (2008) Model Baru Perancangan Kota yang Kontekstual: Kajian tentang Kawasan Tradisional di Kota Semarang dan Yogyakarta, Suatu PotensiPerancanganKotayangEfektif(Indonesian). Yogyakarta, Indonesia: Penerbit Kanisius. 